\title{
A Look at the Relationship of Curriculum and Instruction and the Art and Science of Teaching
}

\author{
Lee Hatch Flake ${ }^{1}$ \\ 'Nagasaki University Japan
}

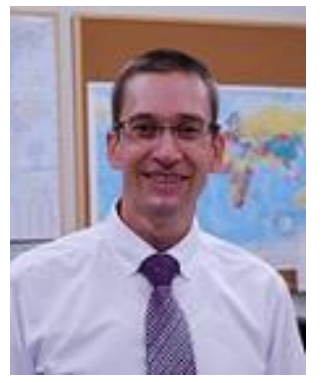

\begin{abstract}
The definition of instruction and curriculum may take on different meanings based on the purpose or interpretation whether political, social, or educational. Teaching effectively requires the skill of a knowledgeable and experienced educator. Teaching can be convincingly debated as being an art or a science or defined collectively as an art and a science. The different approaches and ways to teach make teaching an art but the necessary knowledge of the material being taught makes teaching a science. An understanding of teaching as an art and a science enables educators to teach more effectively by providing perspective on different teaching approaches.
\end{abstract}

Keywords: Curriculum, Instruction, Teaching.

Citation | Lee Hatch Flake (2017). A Look at the Relationship of Curriculum and Instruction and the Art and Science of Teaching. Asian Journal of Education and Training, 3(2): 82-85.

History:

Received: 27 July 2017

Revised: 25 August 2017

Accepted: 1 September 2017

Published: 7 September 9017

Licensed: This work is licensed under a Creative Commons

Attribution 3.0 License (oc)

Publisher:Asian Online Journal Publishing Group
Funding: This study received no specific financial support.

Competing Interests: The author declares that there are no conflicts of interests regarding the publication of this paper.

Transparency: The author confirms that the manuscript is an honest, accurate, and transparent account of the study was reported; that no vital features of the study have been omitted; and that any discrepancies from the study as planned have been explained.

Ethical: This study follows all ethical practices during writing.

\section{Contents}

1. Introduction

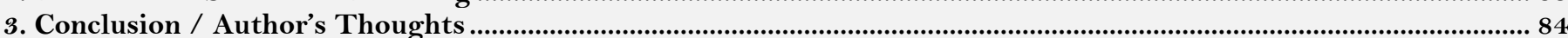

References. 


\section{Introduction}

The definition of instruction and curriculum is subjective. Both curriculum and instruction may take on different meanings based on the purpose or interpretation whether political, social, or educational. Curriculum is what is taught in schools, instruction is how curriculum is delivered and learning is what knowledge or skill has been acquired (Wiles et al., 2002). The most common definition of curriculum is based on overt curriculum which supports an intentional instructional agenda of an educational institute (Wilson, 2005). Furthermore, curriculum is the content of what is being taught and instruction is the implementation of teaching according academic curriculum.

According to Random (2016) the term instruction is derived from the late Middle English word instruccioun meaning to provide structure and direction. Curriculum is derived from the Latin word currere which is associated with the idea of running a racecourse (Hlebowitsh, 2005). This author, as a marathon runner, finds interest in this comparison. Running an open course with a direction or goal in mind maintains more interest than the boredom of running around a track. The changes in scenery and terrain, curves and straights, inclines and declines in conjunction with weather changes make an open course more interesting. Likewise, changes disrupt and redirect the course of curriculum development making the course which curriculum takes more interesting than circling a predictable track. Curriculum closely follows or is imposed to counteract the influence of changes-especially social forces have a profound influence on curriculum (Wiles et al., 2002). Changes alter conventional wisdom as new fields of knowledge are constantly being developed. Technology is an example of such changes. Technology is always changing and has a direct influence on curriculum trends and development. Political agendas might also have an influence on curriculum development. Changes in curriculum also coincide with paradigm shifts in knowledge and the necessity of knowledge. For example, learning shorthand is no longer a skill that is necessary in this age. Such programs are removed from curriculum that was once considered standard decades ago. Environmental changes have also sparked curriculum such as "Green Education" in schools around the world. "Peace Education" is a curriculum standard in Japan. Demographic changes and globalization also influence curriculum as in the case of bilingual and ESL education in the United States.

The relationship between curriculum and instruction is intimate. The relationship being so intimate that curriculumandinstruction is often said as though the terms are one word. Yates (2000) further introduces curstruction and instriculum as morphed words to describe the seemingly inseparable relationship between curriculum and instruction. One of the views Hlebowitsh (2005) provides describes curriculum as providing structure, outline and purpose to experiences in school; however, the author does not limit curriculum to this single definition.

This author would describe the relationship between curriculum and instruction as a parent and child relationship. Curriculum takes the role of a parent who is independent and may function without instruction; whereas, academic instruction is inherently dependent upon curriculum-much like a child is dependent upon a parent. Curriculum provides direction for instruction since instruction is the method of delivering academic curriculum. Instruction may exist without curriculum but would serve no direct purpose. Curriculum and instruction must be compatible and maintain a close relationship in order to maximize student learning. The design of curriculum influences student learning. Curriculum is a vessel that helps learners gain knowledge, develop skills and broaden understanding and has outcomes that may be measured (Yates, 2000). Instruction, on the other hand, is as capricious as an unpredictable child. The design of instruction is influenced by an educator's philosophy and instructional beliefs. Instruction design is developed according to curriculum but maintains individuality while being dependent upon curriculum and standards. The prioritization of information found in overt curriculum and what instruction techniques are used is reflected by a teacher's philosophy. Teachers are individuals composed of different biases, attitudes, and personal philosophy-this human element plays a role in instructional practices. Teachers instruct according to their personal philosophy.

Curriculum and instructional design alters according to society and is influenced by new technology and information. The parent-child relationship of curriculum and instruction suggests opportunity for growth as both the parent and child learn from each other. Knowledge of the relationship between curriculum and instruction may help educators strive to provide a quality education to students.

\section{The Art and Science of Teaching}

Teaching effectively requires the skill of a knowledgeable and experienced educator. An understanding of the definition of teaching aids the educator by providing perspective on different teaching approaches. Teaching can be convincingly debated as being an art or a science or defined collectively as an art and a science. The different approaches and ways to teach make teaching an art but the necessary knowledge of the material being taught also makes teaching a science. To properly assess the full spectrum of approaches which teaching encompasses, it is important to understand the different concepts concerning and defining teaching as an art and a science.

\subsection{Teaching as a Science}

Science refers to skills and knowledge that are uniform and structured. The science of teaching is also in reference to the credentials and qualifications of the teacher. Standards are scientific as they are used to represent an absolute. Standards used to test a teacher's knowledge and ability is based upon pre-determined criteria. The tests to determine aptitude have the standards and criteria down to a science. However, such criteria does not calculate the teacher's individual personality traits and ability based on the attitude and character of the instructor. A teacher with knowledge might not be able to reach students as effectively as one who, although less knowledgeable, is entertaining and witty. However, the science=knowledge aspect of teaching might also represent a specific learned skill.

An instructor's teaching portfolio is another example of how teaching is also a science. The term "portfolio" is often used by artists to represent a collection of an artist's noted works that give evidence of the artist's skills, ability and talent. Likewise, an instructor's portfolio is a collection of samples that demonstrates the teacher's knowledge, skills and ability (Frederick et al., 2000). 
The author has found through experience that there is an extreme difference between teaching youth and adults. After teaching adults at university and at various language academies, the author thought of teaching as a science. Teaching was a matter of knowledge being reiterated to the class. Aged students have a different attitude concerning education; most adult students learn because they have personal interest in study, not because education is imposed on them. Experimentation with different lesson material in order to find what was effective was irrelevant as to the actual material being taught when concerning adult students. The author's experiences of education in the university setting were also a science as skills and knowledge were uniform and structured. Standards used to assess the class and the author, as an instructor, were based on structured criteria. Exams and grading of the students were also based on specific criteria making the content and curriculum of the class a science. To the author's surprise, the class average was also set as a pre-determined average by the university. Although this practice has ended, as an instructor, the author's task was to scientifically calculate the results of the students test scores to conform the pre-determined class average while endeavoring to maintain a fair representation of each student's individual performance in the class. Individuality and personality traits were not part of the calculation to determine teaching credentials. Credentials were based entirely upon knowledge and assessable skills.

However, after taking on teaching contracts with kindergarten-aged youth and working at elementary schools, middle schools, and a high school, the authors has had a paradigm shift to support teaching as also an art and not limited to being a science by self-determining structure and knowledge. An educator with knowledge might not be able to reach a class as effectively as one who is entertaining and humorous. In the university setting, it was not necessary nor was it encouraged to entertain the students. If the teacher is able to capture the attention of the students, the material being taught is more readily absorbed due to the undivided attention of the class. Sometimes it takes a while to get into the groove of teaching and finding exactly what works. In retrospect, the quality of the author's work as an educator during his early days of teaching university courses was perhaps not up to the standard that one should have aimed for. It was not until teaching youth that the author started experimenting with different lesson material and instruction strategies. The author was concentrating more on the work or course material and conforming to the syllabus than the students. The author has since come to realize that although knowledge of material being taught is essential, teaching purely as a science neglects those who are being taught. Teaching is not simply regurgitating information, it is the expression and personalization of the information that makes the educator unique and gives "flavour" to the information being taught.

\subsection{Teaching as an Art}

In teaching, as in art, there is no consistency. Fine art is expressed through many different styles including impressionism, mannerism, modern, Romanesque, Baroque, classic, abstract, Asian, Coptic, Byzantine, and the list continues (Zeroland, 2016). Likewise, the art of teaching takes on many different styles including the Cognitive Approach, Total Physical Response, Natural Approach, Direct and Indirect Instruction Methods, Discussion, Cooperative, and Self-Directed Instruction as well as Functional Approaches are examples of the numerous teaching styles (Krueger et al., 2000). There are countless ways to teach. As there are many different styles in art, there are also many styles in teaching.

How teaching is performed also makes teaching an art. Teaching performance is based on competence for a variety of genres besides scholastic subjects such as narration, computers, dance, drama, instrumental music, and art. How a subject is being taught is directly related to the effectiveness of the lesson. Teaching requires intuition which is ideally described as an art (Brumfit and Johnson, 1994).

In art, individualism and expression are the norm. As in teaching, there are numerous styles and approaches on teaching. The attributes that make a teacher effective and able to reach the students might be unique to the individual. A certain disposition and one's individual way of expression, such traits are difficult to duplicate. A knowledgeable educator might not necessarily be an effective educator since it is often the personal attributes of the educator that capture the attention of the student.

When teaching young children who have extremely short attention spans, it is important to alter the material being taught and find an entertaining approach. During the author's early years as a kindergarten instructor, he felt that his lessons were simply to keep the children entertained and English instruction was secondary. It was not until the author received some advice and helpful teaching material from senior instructors that he was able to teach the children effectively. To teach young children requires a Total Physical Response approach on teaching; it is impossible to keep such young students attention without involving movement in the teaching. The author had previously experienced teaching university students and adult classes at a language academy. Teaching methods between the adults and the young kindergarten children were in total contrast of each other. What is effective in one classroom is absurd in another. Likewise, as the author taught junior high children and teenagers at high school, he learned that as the age of the students increase or decrease the teaching techniques must also change to conform to the age of the students. Among the same age groups there are also variations depending upon the atmosphere and the "feel" of the classroom. What works in one classroom might not in another. Games are enjoyed by all (even adults), however, it is the sophistication of the game that makes it appealing to each age group. Finding what works and learning how to read the "feel" of the classroom is a learned talent that every instructor endeavors to foster. Such skills are what contribute to the definition of teaching as an art and not merely a science.

\section{Conclusion / Author's Thoughts}

Interpretation, perception and reception of information suggest that not only teaching but learning also is an art and a science. Individual learning styles are often unconsciously used as teaching styles by educators. If the class is comprised of kinesthetic or tactile learners, and the instructor is a visual learner, then the instructor is more likely to teach visually rather than kinesthetically or tactually. Teaching styles are affected by individual perception and internalized knowledge (Rivers and Temperley, 1978). In the author's opinion, although teaching is both an art and a science, the art aspect of teaching is more evident in modern teaching strategies. Technology and different teaching styles share the same purpose of trying to maintain the student's attention and interest. To motive the 
class and keep the students interested in learning is a challenge. Students need to be taught to be involved in their own learning. Distractions and lack of attention in the class prevents students from obtaining their learning potential (Owca et al., 2003).

In the author's opinion, the science "knowledge" variable is much less important than it was a century ago. With the Internet, teachers and institutes no longer have a monopoly on knowledge and information. History has proven that knowledge is subjective and might differ from truth. Science adjusts its views according to research and evidence. What was once considered scientific truth is sometimes proven incorrect through time. Deductive and inductive logic also dictate that information may be manipulated to produce certain results. Information is not an absolute. As James (1989) stated over a hundred years ago "teaching is an art; and sciences never generate arts directly out of themselves." Education is not a pure science, if education was purely a science than any educated individual could teach. Unfortunately, teaching is not about simply repeating information to the class as much as it is in the presentation of the information and creating a desire within the students to find out knowledge of truth for oneself. James (1989) stated that “...in teaching, (one) must simply work your pupil into such a state of interest in what you are going to teach him that every other object of attention is banished from his mind; then reveal it to him so impressively that he will remember the occasion to his dying day; and finally fill him with devouring curiosity to know what the next steps in connection with the subject are." Skillful educators make information understood in an entertaining way. An educator with excellent knowledge (science) might not be able to captivate the interests of the class compared to an entertaining instructor with excellent presentation skills (art). Effective educators possess a personality which is naturally captivating and unique to the individual reinforcing the humanistic approach that teaching is an art. Unfortunately, not everyone has the disposition and personality to be entertaining in the classroom. It is also good to be true to oneself and find a teaching style that works matching one's own personality. Students are people and all people are the unpredictable and ever-changing element of any system making methods of teaching that were effective in the past become less effective as the student's attention spans become shorter. Attributes that are unique to the individual-compassion, kindness toward the students combined with a sense of humor or somehow making the lesson material more exciting and interesting helps. Finding what is effective is a day-by-day and a class-by-class effort. Discovering what teaching style is most effective takes time. Experience and endeavors of the instructor are important for an educator to learn the art and science of teaching.

\section{References}

Brumfit, C.J. and K. Johnson, 1994. The communicative approach to language teaching. 8th Edn., Oxford University Press. pp: 21.

Frederick, L., R. McMahon and L.E.J. Shaw, 2000. Preservice teacher portfolios as autobiographies. Education, 120(4): 634-638. View at Google Scholar

Hlebowitsh, P.S., 2005. Designing the school curriculum. 1st Edn., Boston, MA: Pearson Custom Publishing.

James, W., 1989. Talks to teachers on psychology. Psychology and the Teaching Art, 83(496): 155

Krueger, K., J. Saul and P.Y. Lin, 2000. The learning curve. Teaching Styles. Available from library.thinkquest [Accessed February 8, 2014].

Owca, S., E. Pawlak and M. Pronobis, 2003. Improving student academic success through the promotion of listening skills. Reference Number ED478233: 60.

Random, H., 2016. Random house unabridged dictionary. Retrieved from http://dictionary.reference.com/browse/instruction $[$ Accessed October 4, 2016].

Rivers, W.M. and M.S. Temperley, 1978. A practical guide to the teaching of english as a second or foreign language. Oxford University Press. pp: 63.

Wiles, J., J. Bondi and E.J. Sowell, 2002. Foundations of curriculum and instruction. Boston, MA: Pearson Custom Publishing.

Wilson, L.O., 2005. Wilson's curriculum pages. Retrieved from www.uwsp.edu [Accessed September 13, 2011 1].

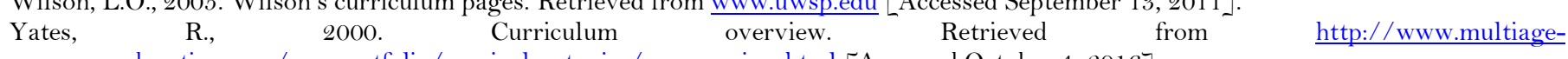
education.com/russportfolio/curriculumtopics/curoverview.html [Accessed October 4, 2016].

Zeroland, 2016. Arts online: Art movements art periods and art styles. Retrieved from http://zeroland.co.nz/directory/visualarts/art_movements/ [Accessed September 15, 2016]. 